\title{
FEBRUARY MEETING.
}

The regular meeting of the society was held in the Law Lecture Room of the University Building, on Friday evening, Feb. 6th, 1891.

The meeting was called to order at 8:45, President G.F. Barker, in the chair.

The minutes of the January meeting were read, amended and accepted as amended.

The election of new members being in order the following were elected as members :

Geo. H. Clapp, 955 th Ave, Pittsburgh, Pa.

Dr. H. Carrington Bulton, University Club, N. Y. City.

Wm. D. Crumbie, U. S. Laboratory, 402 Washington St., N. Y.

F. E. Dodge, care of N. Y. Tartar Co., 9th St. and Gowanus Canal, Brooklyn, N. Y.

J. T. Evans, 606 Montgomery St., San Francisco, Cal.

Prof. L. P. Kinnicutt, Polytechnic Institute, Worcester, Mass.

Prof. Rachel Lioyd, Univ. of Neb., Lincoln, Neb.

Prof. E. F. Ladd, North Dakota Agricult. College, N. D.

Prof. Hudson H. Nicholson, Univ. of Neb., Lincoln, Neb.

Edward Scherer, U. S. Laboratory, 402 Washington St., N. Y.

Albert H. Welles, N. Y. Tartar Co., 9th St. and Gowanus Canal, Brooklyn, N. Y.

C. H. White, Mare Island Navy Yard, Cal.

For associate membership :

Prof. P. W. Bedford, 66 Duane St., N. Y.

D. H. Burrell, Little Falls, N. Y.

Prof. Chester Huntington, Flushing, I. I.

The following proposals for membership were then read :

Francis C. Blake, Penusylvania Lead Co., Mansfield Valley, Allegheny Co., Pa. 
C. P. Gundy, Eliza Furnace, Pittsburgh, Pa.

M. De L. Haigh, care of Meyers Bros. Drug Co., St. Louis, Mo. Henry Heim, East Saginaw, Mich.

Wm. Heim, East Saginaw, Mich.

Prof. J. L. Jarman, Emory and Henry College, Emory, Va.

G. A. Kirchmaier, City Chemist, Toledo, 0 .

Oliver S. Jedman, 9 N. High St., Columbus, 0 .

Edw. D. Eearce, care of T. P. Shepard \& Co., Providence, R.\&I.

J. D. Penhock, care of Solway Soda Co., Syracuse, N. Y.

Prof. F. C. Robinson, Bowdoin College, Brunswick, Me.

Herbert W. Snow, care of F. Stearns \& Co., Detroit, Mich.

C. W. Teeter, Peoria, Ill.

E. Fred. Wood, 85 Fifth Ave, Pittsburgh, Pa.

For associate membership :

L. D. Arnold, Rumford Chemical Works, Providence, R. I.

The reading of papers being next in order, Mr. J. F. Geisler read a paper on the "Signification of Lactometer Tests."

Dr. A. R. Leeds read the following papers: "Estimation by Titration of Dissolved Carbon Dioxide in Water." Discussion by Messrs. Barker, Breneman, Doremus, Kent, Hallock, Pellew and others.

"On the Precipitation of Suspended Clay by Aluminic or Ferric Hydroxides, or by means of Calcium Hydrate." Discussion by Messrs. Pellew, Hallock and Breneman.

"On the Proteids of Cow's Milk." Discussion by Messrs. Breneman and Pellew.

As there was no further business, the meeting was then adjourned.

Durand Woodman,

Rec. Sec'y. 